Table 2. $O$ contents and $A E S$ results for $\mathrm{Si}_{3} \mathrm{~N}_{4}$ ceramic powders.

\begin{tabular}{|c|c|c|c|c|c|c|}
\hline \multirow[b]{2}{*}{ No. } & \multirow[b]{2}{*}{ Type/origin } & \multirow[b]{2}{*}{$\begin{array}{l}\mathrm{O} \text { content } \\
\text { (wt \%) }\end{array}$} & \multicolumn{2}{|r|}{$\mathrm{O} / \mathrm{N}$ (at.) } & $d^{\mathrm{D}}$ & \multirow[b]{2}{*}{$-\mathrm{O} / \mathrm{N}(d)^{\mathrm{b}}$} \\
\hline & & & area & $\begin{array}{l}\text { point } \\
\text { analysis }\end{array}$ & $\frac{a}{\mathrm{~nm}}$ & \\
\hline 1 & LC12/H. C. Starck & 1.3 & 0.28 & $0.11 \pm 0.02$ & $(9)^{c}$ & noc \\
\hline 2 & SNB/Denka & 2.7 & 0.83 & $0.51 \pm 0.10$ & 38 & yes \\
\hline 3 & SN9FW/Denka & 0.7 & 0.07 & $0.13 \pm 0.04$ & 16 & yes \\
\hline 4 & SNE10/Ube & 1.3 & 0.60 & $0.13 \pm 0.07$ & 7 & yes \\
\hline 5 & A200/Toshiba & 2.2 & 0.40 & $0.14 \pm 0.14$ & 8 & yes \\
\hline $\begin{array}{l}{ }^{2} \mathrm{Re} \\
{ }^{\mathrm{D}} \mathrm{Di} \\
{ }^{\mathrm{C}} \mathrm{O} \\
0.0\end{array}$ & $\begin{array}{l}\mathrm{nce}^{\mathrm{b}}: \mathrm{Ta}_{2} \mathrm{O}_{5} / \mathrm{Ta} \text {. } \\
\mathrm{ct} \mathrm{O} / \mathrm{N} \text { decrease wit } \\
\text { a slight decrease } \\
0.025 \text { at } 18 \mathrm{~nm} \text { wa }\end{array}$ & $\begin{array}{l}\text { pth. } \\
\text { the } O / N \\
\text { served. }\end{array}$ & ratio & om $0.098 \pm C$ & 2 at & $=0 \mathrm{~nm}$ to \\
\hline
\end{tabular}

\begin{tabular}{|c|c|c|c|c|c|c|c|}
\hline Element & $\mathrm{Ca}$ & $\mathrm{Fe}$ & $k$ & Si & Al & 0 & $\mathbf{s}$ \\
\hline wt $\%^{a}$ & 1.11 & 9.40 & 1.88 & 22.8 & $14^{b}$ & $-\mathbf{b}$ & $-b$ \\
\hline at. $\%$ c & 1 & 5 & 1 & 25 & 16 & 52 & - \\
\hline Grain $1^{d}$ & 3 & 28 & 1 & 15 & 15 & 38 & 0 \\
\hline Grain $2^{d}$ & 2 & 9 & 1 & 30 & 23 & 33 & 1 \\
\hline
\end{tabular}

As certified.

Dot certified, Al value given for information.

c Recalculated.

${ }^{d}$ Rounded mean at. $\%$ between 30 and $70 \mathrm{~nm}$ (ref. $\mathrm{Ta}_{2} \mathrm{O}_{5} / \mathrm{Ta}$ ) by AES point analysis.

smaller than area ones, which might be due to hydroxyl condensation or $O$ diffusion under intense irradiation. Sample no. 1 might show the limits of the method, because no distinct depth profile could be attained starting with an $\mathrm{O} / \mathrm{N}$ ratio of 0.1 .

Environmental analysis: rivulet sediments and coal fly ash. The main question as to whether different chemical compositions and depth profiles between different grains could be attained, can be positively answered: as for the sediment, a C-rich layer of about $10 \mathrm{~nm}$ thickness covers inorganic oxidic substances containing different $\mathrm{Al}$ and $\mathrm{Si}$ concentrations (20 to 40\%). Differences were also seen for the minor constituents $\mathrm{K}, \mathrm{Ca}$, and $\mathrm{Fe}$ (all between 0 and $4 \%$ ), which were enriched at the surface or covered by the C-layer and/or distributed homogeneously in greater depths $(\leqslant 100 \mathrm{~nm})$. Similar qualitative observations could be made on coal fly ash for which specified and found contents are listed in Table 3. No elements with percentages below 1 could be detected, except $P$ (in a surface or intermediate layer) and $S$, both not specified.

\section{CONCLUSION}

In spite of the main limitations (beam drift, particle size and applicable beam current (charging)) there is still enough space for AES measurements on poorly conducting particles. However, these measurements are tedious because of manual drift corrections and delays after sputtering, and because large amounts of particles must be analysed to obtain quantitative results. Therefore, automatic image shifts compensating for drifts and more sophisticated techniques of sample preparation (dense monolayers of non-agglomerated particles) are required.

\section{Acknowledgements}

This work has been supported by the Bundesminister für Forschung und Technologie and the Ministerium für Wissenschaft und Forschung des Landes Nordrhein-Westfalen. Frau S. Wübbold (Universität Marburg) provided the sediments.

\section{REFERENCE}

1. L. E. Davis et al., 'Handbook of Auger Electron Spectroscopy', Perkin-Elmer Corp., Eden Prairie (1978).

\title{
Microstructure of Fe Implanted Yttria Stabilized Zirconia Studied by Mössbauer Spectroscopy and TEM
}

\author{
D. Scholten, B. A. Boukamp and A. J. Burggraaf \\ University of Twente, Dept of Chemical Engineering, Laboratory of Inorganic Chemistry, Materials Science and Catalysis, \\ P.O. Box 217, 7500 AE Enschede, the Netherlands
}

\section{INTRODUCTION}

The solid solutions of zirconium and yttrium oxides, $\left(\mathrm{ZrO}_{2}\right)_{1-x}\left(\mathrm{Y}_{2} \mathrm{O}_{3}\right)_{x}$, abbreviated $\mathrm{ZY} \times 100$, are well known high temperature oxygen-ion conducting solid electrolytes and are used in applications like oxygen sensors, oxygen pumps and fuel cells. ${ }^{1}$ For these applications an electronically conducting electrode material on top of the solid electrolyte is necessary. Conventionally porous noble metal $(\mathrm{Pt})$ electrodes are used, but mixed (electronic and ionic) conducting materials are applied too. ${ }^{2-4}$ Such a mixed conducting layer can also be 
obtained by implantation of a suitable ion. Top layers formed by implantation have the advantage that they can be made very thin and that no sharp interface exists between the top layer and electrolyte. The electrochemical ${ }^{5,6}$ and other properties depend on the microstructure of the implanted layer which is discussed here.

\section{EXPERIMENTAL}

Both single crystal and ceramic ZY17 was implanted with high doses of $\mathrm{Fe}\left(2\right.$ and $8 \times 10^{16} \mathrm{Fe} \mathrm{cm} \mathrm{cm}^{-2}$ at $15 \mathrm{keV}$ and $8 \times 10^{16} \mathrm{Fe} \mathrm{cm}^{-2}$ at $\left.110 \mathrm{keV}\right)$ at the Laboratory for General Physics (L.A.N.) of the State University of Groningen. Chemically prepared ZYFel0 (ZY17 containing $10 \mathrm{~mol} \% \mathrm{Fe}_{2} \mathrm{O}_{3}$ ) samples ${ }^{5,7}$ were used as comparison in the Mössbauer experiments. The microstructure was studied with a Jeol-200 CX microscope on samples thinned by ion milling. The implantation profiles were measured at the RBS facility of the L.A.N. The structural disorder introduced by the implantation in single crystal ZY17 was investigated with channelling experiments. The charge and environment of the implanted Fe was probed with conversion electron Mössbauer spectroscopy (CEMS). The integral CEMS mode was used and samples were coated with a $20 \mathrm{~nm}$ thick carbon layer to avoid surface charging. A detailed account of the Mössbauer experiments will be published separately. ${ }^{8}$

\section{RESULTS AND DISCUSSION}

The shapes of the concentration profiles of $\mathrm{Fe}$ did not change during thermal treatments up to $900^{\circ} \mathrm{C} .{ }^{9}$ TEM observations on as-implanted high dose samples $\left(8 \times 10^{16} \mathrm{Fe} \mathrm{cm} \mathrm{cm}^{-2}\right)$ showed the formation of a granular substructure, with crystallites of $30 \mathrm{~nm}$, within the original grains (grain size $\geqslant 0.5$ micron). Diffraction patterns of these grains show, in addition to the cubic $\mathrm{ZY}$, also the reflections of $\mathrm{Fe}_{2} \mathrm{O}_{3}$. All reflections appear as diffuse rings indicating that both the $\mathrm{ZY}$ and $\mathrm{Fe}_{2} \mathrm{O}_{3}$ are fine grained and randomly oriented. Dark field images of the $\mathrm{Fe}_{2} \mathrm{O}_{3}$ reflections show very fine grained precipitates $(<5 \mathrm{~nm})$ dispersed through the matrix. These precipitates seem to grow with a heat treatment at $1100^{\circ} \mathrm{C}(30 \mathrm{~min})$.

Combination of RBS and channelling experiments on implanted ZY17 single crystals showed that annealing up to $800^{\circ} \mathrm{C}$ does not restore the ordering in the $\mathrm{Zr}$ sub-lattice. Together with the TEM results this indicates a recrystallization of the single crystalline matrix in a random way. For polycrystalline samples it was found that in the Rutherford backscattering spectrum the step height at the oxygen edge decreased after $\mathrm{Fe}$ implantation. After oxidation at $400^{\circ} \mathrm{C}$ it increased again, indicating loss of oxygen during implantation.

Transmission Mössbauer spectra were made of 'standard' ZYFe10 samples of known Fe concentration and microstructure. ${ }^{1}$ Besides the doublet (isomer shift, I.S. $=0.23 \mathrm{~mm} \mathrm{~s}^{-1}$ and quadrupole splitting, Q.S. $=1.24 \mathrm{~mm} \mathrm{~s}^{-1}$ ) another slight adsorption at -4.3 and $5.0 \mathrm{~mm} \mathrm{~s} \mathrm{~s}^{-1}$ was observed. These peaks are part of a sextuplet originating from $\mathrm{Fe}_{2} \mathrm{O}_{3}$ particles larger than $10 \mathrm{~nm} .{ }^{10}$ The conversion electron Mössbauer spectra (CEMS) of the ${ }^{57} \mathrm{Fe}$ implanted materials are very complex. The spectra for annealed samples gave $I . S$. values comparable to that of ZYFe10, indicating that all of the iron is present in the $\mathrm{Fe}^{3+}$ state. Computer fits with only one $\mathrm{Fe}^{3+}$ site all yielded systematic deviations. Better fits were obtained assuming two types of $\mathrm{Fe}: \mathrm{Fe}_{\mathrm{s}}^{3+}\left(I . S .=0.24-0.25 \mathrm{~mm} \mathrm{~s}^{-1}\right.$ Q.S. $\left.=1.43-1.48 \mathrm{~mm} \mathrm{~s}^{-1}\right)$ and $\mathrm{Fe}_{\mathrm{h}}^{3+}\left(I . S .=0.24-0.25 \mathrm{~mm} \mathrm{~s}^{-1}\right.$, Q.S. $=0.86-0.90 \mathrm{~mm} \mathrm{~s}^{-1}$ ). These doublets are ascribed to $\mathrm{Fe}^{3+}$ substitutionally incorporated for $\mathrm{Zr}^{4+}\left(\mathrm{Fe}_{\mathrm{s}}^{3+}\right)$ and very small $\mathrm{Fe}_{2} \mathrm{O}_{3}$ precipitates $(<5 \mathrm{~nm}), \mathrm{Fe}_{\mathrm{h}}^{3+}$. The $\mathrm{Fe}_{\mathrm{h}}^{3+}$ component is also found in $\mathrm{MgO}$ implanted with $\mathrm{Fe}^{11}$ and is explained by the occurrence of super-paramagnetism in $\mathrm{Fe}_{2} \mathrm{O}_{3}$ particles smaller than $10 \mathrm{~nm}^{10,12}$

The as-implanted spectra could be described using this model and two additional doublets and a sextuplet. Of the extra doublets one has been ascribed to $\mathrm{Fe}^{2+}(I . S .=0.91 \mathrm{~mm}$ $\left.\mathrm{s}^{-1}, Q . S .=2.01 \mathrm{~mm} \mathrm{~s}^{-1}\right)$, the other $\left(I . S .=-0.07 \mathrm{~mm} \mathrm{~s}^{-1}\right.$, $Q . S .=0.45 \mathrm{~mm} \mathrm{~s}^{-1}$ ) to iron dimers. ${ }^{11}$ The additional sextuplet was ascribed to relatively large iron particles. Annealing the as-implanted samples at $300-400^{\circ} \mathrm{C}$ results in rapid oxidation of all iron to $\mathrm{Fe}^{3+}$, which is in agreement with the observed increase in the oxygen content (RBS) and strong changes in the electrical properties. ${ }^{6}$ The relative abundance of each $\mathrm{Fe}$ oxidation form could be calculated from the CEM spectra. Using the Fe depth profiles (RBS) a (metastable) solubility level of $4-5 \times 10^{21} \mathrm{Fe} \mathrm{cm}{ }^{-3}$ could be calculated. This is about the same as found for the chemically prepared samples and is about 3 to 4 times higher than the equilibrium solubility. ${ }^{7}$

\section{CONCLUSIONS}

The high dose implantation of $\mathrm{Fe}$ in ZY17 single crystals results in a random recrystallization of the surface layer. In implanted polycrystalline material an intergranular substructure is observed. In the as-implanted state metallic particles, $\mathrm{Fe}^{0}$ dimers and $\mathrm{Fe}^{2+}$ and $\mathrm{Fe}^{3+}$ ions are found, their relative abundance depending on the implantation conditions. After a short anneal at $400^{\circ} \mathrm{C}$ all these different oxidation states are rapidly converted to $\mathrm{Fe}^{3+}$. The maximum implanted $\mathrm{Fe}^{3+}$ concentration that remains (metastable) on the substitutional $\mathrm{Zr}^{4+}$ lattice sites, after a $30 \mathrm{~min}$ anneal at $400^{\circ} \mathrm{C}$, is 4 $5 \times 10^{21} \mathrm{Fe} \mathrm{cm}^{-3}$, the same as found for chemically prepared ZYFe10. Annealing higher dose implantations leads to the exsolution of dispersed and very small $(<5 \mathrm{~nm})$ hematite particles.

\section{Acknowledgements}

The authors are grateful to $\mathrm{Dr}$ du Marchie van Voorthuysen and $\mathrm{Mr}$ Smit of the State University of Groningen for the ion implanter facilities. We want to thank also Prof. Dr Niesen for his help with the Mössbauer experiments and Dr Beyer for his assistance with the TEM measurements. The investigations were supported by the Netherlands Foundations for Chemical Research (S.O.N.) with financial aid from Z.W.O. We acknowledge the support from the CNRS.

\section{REFERENCES}

1. E. C. Subbarao and H. S. Maiti, Solid State lonics 11, 317 (1984).

2. M. P. van Dijk, PhD Thesis, University of Twente, the Netherlands, September 1985.

3. M. P. van Dijk, K. J. de Vries and A. J. Burggraaf, Solid State Ionics 21, 73 (1986).

4. Y. Takasu, T. Sugini and Y. Matsuda, J. Appl. Electrochem. 14, 79 (1984).

5. D. Scholten, PhD Thesis, University of Twente, the Netherlands, April 1987.

6. A. J. Burggraaf, A. J. A. Winnubst and D. Scholten, presented at the 6th Int. Conf. on Solid State lonics, GarmischPartenkirchen. September 1987, to be published in Solid State ionics.

7. A. J. Burggraaf, A. J. A. Winnubst and D. Scholten, to be published.

8. A. J. Burggraaf, D. Scholten and L. Niessen, to be published.

9. D. Scholten and A. J. Burggraaf, Surf. Interface Anal. 9, 467 (1986).

10. W. Kundig, H. Bömmel, C. Constabaris and G. H. Lindquist, Phys. Rev. 142, 327 (1966).

11. A. Perez, J. P. Dupin, O. Massenet, G. Marest and P. Bussière, Rad. Effects 52, 127 (1980).

12. J. M. Friedt and J. P. Adloff, Comt. Rend. 226C, 1733 (1986). 